\title{
NGOs, the Judiciary and Rights in Bangladesh: Just Another Face of Partisan Politics?
}

Adeeba Aziz Khan

\author{
Keywords \\ Bangladesh, Courts, Judges, Judiciary, Judicial Independence, Judicial Activism, \\ Corruption, Constitutionalism, New Democracies, NGOs, Politics, Media
}

\section{Introduction}

On 16 December 1971, Bangladesh emerged as an independent state after a 267-day war against Pakistan. The Bangladesh Liberation War is known as one of the worst genocides of the 20th century that killed, according to some estimates, 3 million Bengalis.1 Bangladesh's independence came from a legacy of rights violations through internal colonization and against the backdrop of genocide. Formerly known as East Bengal and East Pakistan, Bangladesh operated under colonial rule for centuries: the loss of Nawab Sirajjudawllah's throne to the British was followed by the exploitation of its eastern territory by West Pakistan. After living under the domination of the British, Bengali Hindus and West Pakistani Muslims, Bangladeshis became their own masters under the leadership of Bengali Muslims for the first time in 1971.2 Under British colonization and West Pakistani economic colonization, Bangladeshis experienced rights only as the subjects of an imperial ruler and had few opportunities for self-realization. Kamal Hossain, an eminent Bangladeshi jurist, notes that "in a colonial society, a person was the subject of an imperial ruler, whose viceroys exercised executive authority without constitutional limits. They were thus under no constitutional obligation to respect the fundamental rights of their subjects, nor in these societies could the subjects seek judicial protection of their rights.' ' $^{3}$

1 Bangladesh Genocide Archive <http://www.genocidebangladesh.org/ > [last accessed on 2 May 2012].

2 S. Ahmed, Bangladesh: Past and Present (APH, 2004) at 1.

3 K. Hossain, 'The Role of the Judiciary as a Catalyst of Social Change' <http://www. supremecourt.gov.pk/ijc/Articles/9/3.pdf> [last accessed 27 October 2012] 
Following Bangladesh's independence, citizens were provided with fundamental rights fully recognized by law. The 1972 Constitution, adopted by a newly formed Bangladesh, was a beacon of hope for Bangladeshis. The Constitution guaranteed fundamental rights and was based on the principles of nationalism, democracy and socialism. The incorporation of a Bill of Rights in the Constitution and the conferment of the power of judicial review "enabled the judiciary to play a dynamic role in facilitating and promoting social change" ${ }^{4}$ However, since 1971, Bangladesh has witnessed a number of coup d'états that resulted in two long periods of authoritarian military government. Democratic norms and civil liberties have been hard to establish due to frequent intervention in state affairs and the absence of democracy 5 To make matters worse, frequent tampering with and the suspension of the Constitution resulted in a volatile political system and an ineffective government. Bangladesh returned to democracy in 1991 in the wake of mass uprisings when political parties united to fight President Ershad's ten year authoritarian rule (1982-1991). A fragile democracy remains in place today, despite a two year emergency declared by the military-backed caretaker government in 2007 and $2008{ }^{6}$ Zafrullah notes that in Bangladesh "there is a lack of political consensus, weak legislative authority, unhealthy modes of political competition, undemocratic political party structures, political and administrative patronage, and weak local governance. All these problems have produced social tension, a lack of equal access to natural justice and abuses of human rights.']

Despite executive interference and a lack of separation, the judiciary has been applauded for its role in upholding human rights. At the head of the judiciary is the Supreme Court of Bangladesh, comprised of the High Court and Appellate Divisions. The thriving non-governmental organization ("NGO") network in Bangladesh is also credited with bringing gains in the economic and social rights of the poor. Literature on the higher judiciary in Bangladesh, especially with respect to public interest litigation ("PIL"), generally accepts that the expansion of judicial review and a proactive approach has enabled the judiciary to draw upon constitutional provisions in order to promote social change. For example, Hossain writes that

4 Ibid.

5 For a detailed discussion of the Bangladeshi military era see D. Lewis, Bangladesh: Politics, Economy and Civil Society (CUP, 2011).

6 Ibid. at 3.

7 H. Zafrullah and M. Rahman, 'Human Rights, Civil Society and Non-Governmental Organizations: The Nexus in Bangladesh', (2002) 24 Human Rights Quarterly 1011 at 1013. 
[t]he judiciary has been promoting social change through rightsfriendly interpretations of the Constitution aimed at implementation of economic and social rights. The increasingly positive attitude of the judiciary towards public interest litigation, overcoming earlier inhibitions, which had constrained the role of the judiciary, has enabled the judiciary to play a dynamic role in facilitating and promoting social change $]^{8}$

NGOs in Bangladesh have played a leading role in upholding rights by bringing democracy back to Bangladesh, promoting awareness of legal rights and providing legal support through the use of rights advocacy for the development of civil, economic, political, and social rights through PIL 9

This paper analyses how the political mood surrounding PIL initiated by NGOs at the Supreme Court sheds light on the use of the Court as a political forum. It also considers the influence of the political climate on the Court. The analysis results from a review of constitutional and statutory legal rules, case law, academic literature, policy papers and practice-oriented research. Media and human rights reports have also been reviewed. The analysis focuses on two landmark decisions of the Supreme Court that were selected for their capacity to show the influence of the government and opposition parties on NGOs and the Supreme Court. Both the cases also reflect the nature of judicial behaviour at different periods of the post-1991 democratic era, enabling a study of PIL and what influenced it soon after PIL first took off during the period of elected government and then 30 years later during the emergency declared by the army-backed caretaker government in 2007. The high-profile nature of the cases, covered extensively in the media, provides an understanding of the context in which the cases took place. Notably, the significant attention these cases received may have contributed to the pro-rights decisions given by the Supreme Court.

In discussing the judicial development of human rights and the role of NGOs in Bangladesh, the bulk of the literature, which in itself is very limited, has focused on judicial decisions or actions taken by NGOs in promoting human rights. There is little discussion on the backdrop against which these decisions or actions were taken, particularly to what extent the support of the state, the opposition, or public outcry through media intervention encouraged and contributed to the positive role of the courts and NGOs. This study

\footnotetext{
8 Supra, note 3; see also R. Hoque, 'Taking Justice Seriously: Judicial Public Interest and Constitutional Activism in Bangladesh', (2006) 15(4) Contemporary South Asia 399.

9 Supra, note 7 at 1012.
} 
explores the context of the two selected cases and situates them within a discussion of the global movement towards "juristocracy" ${ }^{10}$ considering the question of the proper role of the Bangladeshi judiciary that invokes the power of judicial review to make policy decisions that could be seen to impinge on the role of the executive and the separation of powers. While the judiciary has been giving pro-rights judgments since 1991 and NGOs have been using PIL as a method to hold the executive accountable, court decisions and NGO intervention is frequently fuelled by statist and political motives. While the development of fundamental rights by NGOs and the judiciary in Bangladesh has been based on elite or political interests, the judiciary and NGOs should be applauded for their positive role in protecting human rights.

\section{Framework and state of human rights}

The Constitution of Bangladesh was drafted and adopted through a rushed process in 1972 11 It declared a number of fundamental principles of state policy $!^{12}$ which include nationalism $!_{13}^{13}$ democracy (which includes the guarantee of fundamental human rights and freedoms and respect for the dignity and worth of the human person $\sqrt{14}$ and socialism (meaning economic and social justice) ${ }^{15}$ These principles of state policy are to be a guide in the interpretation of the Constitution and laws of Bangladesh. According to the judgment delivered in Hamidul Huq Chowdhury v Bangladesh $!^{16}$ in the event of a conflict between fundamental principles and rights, the rights will prevail ${ }^{17}$

Constitutionally-entrenched rights include the right to equality, the right to non-discrimination, the rights to life and liberty, safeguards regarding arrest and detention, prohibition of forced labour, freedom of movement, freedom of speech, assembly and association, and the right to property ${ }^{18}$ The Constitution

10 R. Hirschl, Towards Juristocracy: The Origins and Consequences of the New Constitutionalism (Harvard University Press, 2004) at 1.

11 For a detailed study of this process see A.F. Huq, 'Constitution-making in Bangladesh', (1973) 46(1) Pacific Affairs 59.

12 Part II, Articles 8-25, Constitution of Bangladesh.

13 Article 8, Constitution of Bangladesh.

14 Article 11, Constitution of Bangladesh.

15 Article 8, Constitution of Bangladesh.

16 (1982) 34 DLR 190 at 200.

17 I. Omar, Rights, Emergencies and Judicial Review (Kluwer, 1996) at 32.

18 Articles 27, 29, 28, 32, 33, 34, 36, 39, 37, 38, and 42 respectively of the Constitution of Bangladesh. 
also guarantees the protection of the law and to be treated in accordance with the law ${ }^{19}$ Certain social and economic rights are guaranteed for specific segments of the population such as women ${ }^{20}$ peasants and workers ${ }^{21}$ and within certain social sectors such as education 22 It is widely accepted that "human rights and fundamental freedoms are indivisible, the full realization of civil and political rights without the enjoyment of economic, social and cultural rights is impossible" ${ }^{23}$ This perception is also vigorously espoused by civil society and by specific NGOs. Besides constitutionally guaranteeing fundamental rights, Bangladesh has bound itself to upholding human rights law by committing to a number of international human rights treaties ${ }^{24}$ It is therefore obliged to take legislative measures in accordance with the treaties it has ratified and to fully implement them.

Despite the guarantees of fundamental rights within the Constitution, the state of human rights in Bangladesh has been criticized to the extent that it is said that "the boundaries of freedom in Bangladesh are clearly demarcated by the use of crossfire, torture and other potent threats" 25 Successive governments continue to use the Special Powers Act, the Code of Criminal Procedure and the Public Safety Act to suppress political opposition. Extra-judicial killing, police brutality and torture, prolonged detention of citizens without formal charges are common. The 2010 US human rights country report reveals:

Security forces committed extrajudicial killings and were responsible for custodial deaths, torture, and arbitrary arrest and detention. ... Prison conditions at times were life-threatening, lengthy pretrial detention continued to be a problem, and authorities infringed on citizens' privacy rights. ... The government limited freedom of speech and of the press, self-censorship continued, and security forces harassed journalists. The government curbed free-

19 Article 31, Constitution of Bangladesh

20 Article 10, Constitution of Bangladesh.

21 Article 14, Constitution of Bangladesh.

22 Article 17, Constitution of Bangladesh.

23 Proclamation of Teheran, Final Act of the International Conference on Human Rights, Teheran, 22 April to 13 May 1968, A/CONF. 32/41 at 3.

${ }^{24}$ For a list of international human rights treaties ratified by Bangladesh see $<$ http://www. adh-geneva.ch/RULAC/international_treaties.php?id_state $=22>$ [last accessed 27 October 2012].

25 B. Fernando, 'Lawless Law Enforcement and the Parody of Judiciary in Bangladesh' $<$ http://www.humanrights.asia/resources/journals-magazines/article2/0504/forewordshort-stories-about-home-truths-in-bangladesh > [last accessed 27 October 2012]. 
dom of assembly, and politically motivated violence remained a problem. ... Discrimination against women, and violence against women and children remained serious problems, as did discrimination against persons with disabilities and against persons based on their sexual orientation. ... Violence against religious and ethnic minorities still occurred. ... Limits on worker rights and child labor remained problems ${ }^{26}$

Most recently, the failure of law enforcement agencies and the actual lack of fundamental rights and democracy has been highlighted by the disappearance of the central organizing secretary of the opposition, Ilias Ali, and his driver on 17 April 2012. Law enforcement agencies have been unable to discover their whereabouts and the opposition has launched a non-stop agitation movement through the use of hartals (political strikes) and street violence until their safe return ${ }^{27}$ In another case, the government has been unable to locate the killers of a journalist couple, Meherun Runi and Sagar Sarwar, who were murdered in their home on 11 February 2011 28 In terms of economic and social rights, the most recent failure was on 4 April 2012, when one of the largest forceful slum evictions in the history of Dhaka took place in Korail bustee. Despite the government having received permission to proceed from the Supreme Court, provided certain conditions were followed, victims claimed that they were given only one day's notice. NGOs have termed the evictions "inhumane" ${ }^{29}$

Having set out the legal basis of fundamental human rights in Bangladesh and showing the poor human rights record, this article now moves on to an exploration of the state of democracy in Bangladesh, its impact on the independence of the judiciary, and its ability to uphold human rights.

\footnotetext{
262010 Human Rights Report: Bangladesh <http://www.state.gov/j/drl/rls/hrrpt/ $>$ [last accessed 27 October 2012].

27 S. Hammadi and J. Burke, 'Bangladesh police out in force as tension rises over missing politician', The Guardian, 22 April $2012<$ http://www.guardian.co.uk/world/2012/apr/22/ bangladesh-police-tension-missing-politician > [last accessed 27 October 2012].

28 M. Malick, 'UN moved for faster Sagar-Runi probe', BDNews24, 6 March $2012<$ http://www. bdnews24.com/details.php?id $=219684 \&$ cid $=2>$ [last accessed 27 October 2012].

29 BRAC, 'Forceful eviction of Korail Slum' 8 April $2012<$ http://blog.brac.net/2012/04/ forceful-eviction-of-korail-slum.html $>$ [last accessed 27 October 2012].
} 


\section{State of democracy}

The literature describing the state of democracy in Bangladesh since the democratic era began in 1991 reveals the main problem as widespread corruption among politicians and public employees, including the judiciary and law enforcement agencies. Other problems with the democratic system include the increasing use of political violence and "muscle politics" through mastaans (political strongmen) and terrorists; marginal enforcement of the rule of law with access to justice being impaired by corruption and the politicization of state agencies; frequent disruptions to the everyday flow of life through hartals, curfews, and confrontational politics of the street; and the resultant lack of civil rights, basic security, and redress mechanisms from these mutually reinforcing phenomena.

One major cause of Bangladesh's ineffective democracy is the intensity of division between the two major political parties, the Awami League ('AL') and the Bangladesh Nationalist Party ('BNP'). Both the AL and BNP view the other party as illegitimate. According to Time, "[r]ejecting any notion of bipartisanship, both parties seem to keep the nation perpetually on the verge of chaos alternating between state repression or crippling national strikes aimed at toppling the government, depending on who is in power. With politics often reduced to little more than a big brawl, violence infects much of daily life: ${ }^{30}$ Given the dynastic nature of politics, where the parties have significant historical baggage that has carried over from Bangladesh's authoritarian period ${ }^{31}$ the leaders of the two parties today question the very legitimacy of the other to exist, let alone to play a role in politics.

Because of their dynastic nature, the parties are also characterized by a lack of internal democracy with a highly centralized and personalized governance structure vesting near absolute power in the party chairperson. This further compounds the problem as personal rivalries between the two leaders take precedence over real political differences ${ }^{32}$ BRAC's 2006 report terms this "the rise of partyarchy", a system where the winning party enjoys the monopoly of power for the duration of their electoral term ${ }^{33}$ As the report notes, "[t]he innermost circle has de facto command over the entire party, legislature,

\footnotetext{
30 A. Perry, 'Rebuilding Bangladesh', Time 10 April 2006.

31 A. Hossain, 'Anatomy of Hartal Politics', (2000) 40(3) Asian Survey 508.

32 BRAC, 'The State of Governance in Bangladesh 2006' <http://igs-bracu.ac.bd/UserFiles/ File/archive_file/State\%20of\%20Governance\%20in\%20Bangladesh\%202006.pdf> at 16 [last accessed 27 October 2012].

33 BRAC is the largest NGO in Bangladesh.
} 
parliamentary committees, procurement policies, development allocations, bureaucracy and law and order enforcement agencies" 34

This dynastic mode of politics and the extreme centralization of power in the hands of the executive is widely regarded as the most fundamental flaw in Bangladesh's parliamentary democracy. All the other issues of corruption, lack of accountability, exclusionary and confrontational politics, and the partisan use of the judiciary and law enforcement agencies are seen to originate from the unbridled power exercised by the government of the day in harassing the opposition and forcing it to resort to politics of the street to make its voice heard.

Moving politics from the parliament to the street is seen to be a failure of the opposition in questioning the executive and holding it to account. The impotence of the opposition is therefore another criticism levied against Bangladeshi democracy, with the argument being made that the government effectively avoids having to respond to an informed, vigilant, and present opposition everyday that the parliament is in session. This in turn is part of a larger concern of a general lack of accountability in Bangladeshi democracy.

One finding of the BRAC report is that formal accountability mechanisms in Bangladesh are weak. The report notes that " $t$ ] he formal institutions to enable accountability are either absent or underdeveloped" 35 The report identifies weak horizontal legislative accountability from the opposition and members of parliament, parliamentary oversight committees that are restrained by lack of formal authority, and non-functional agencies of horizontal accountability such as the Anti-Corruption Commission, which was started by the government largely under pressure from the international community. This is exacerbated, the report argues, by a lack of formal accountability mechanisms within the judicial system. The report observes that

[j]udges are not accountable for the efficiency or lack thereof of their performance [sic] Corruption in key justice institutions, most notably the lower courts and the police force, is a serious problem. Practices of requiring informal payments for basic services effectively blocks access to the criminal justice system by the poor ${ }^{36}$

\footnotetext{
34 Supra, note 32 at 20.

35 Ibid. at 7.

${ }^{36}$ Ibid. at 63.
} 
As far as accountability in justice institutions and government agencies go, however, petty corruption is only the tip of the iceberg. Politically-motivated appointments and recruitment-distorting initiatives, weakening service delivery, and undermining governance through weak enforcement of the rule of law have a range of other negative impacts on human security and economic development.

\section{State of judicial independence}

An impartial judiciary is fundamental to rule-based governance and to sustaining a culture of accountability rather than one of impunity. As Hossain Mollah notes, a dysfunctional judiciary impacts society more severely than any other dysfunctional institution, as it removes a forum for social grievance and reduces social attachment ${ }^{37}$ Unfortunately, impunity, rather than accountability and law-compliance, appears to be ascendant in Bangladesh ${ }^{38}$ For example, the BRAC report noted that the judiciary in Bangladesh has been particularly affected by the lack of separation of powers, which in turn has affected its ability to function as a forum for upholding the rights of citizens.

The Constitution guarantees independence to all judicial officers unconditionally. This ideal is provided by Article 22, which stipulates that the state shall ensure the separation of the judiciary from its executive organs. The Article then addresses the methods of appointment of the judiciary. However, as the BRAC report concludes, possibly the most serious governance failures in Bangladesh have resulted from a lack of judicial independence. Under the existing system of appointments, the lower judiciary and magistrates are functionally dependent on the executive, being appointed through the administrative service by the Ministry of Establishment and the Ministry of Law, Justice and Parliamentary Affairs. Personnel and spending decisions thus allow for the politicization of key personnel ${ }^{39}$ The Supreme Court issued its Secretary, Ministry of Finance $v$ Md. Masdar Hossain ${ }^{40}$ judgment in 1999 that included 12 directives to strengthen the independence and separation of the judiciary in line with the Constitution. Yet successive governments found it expedient to main-

37 A.H. Mollah, 'Separation of Judiciary and Judicial Independence in Bangladesh' $<$ http: //unpan1.un.org/intradoc/groups/public/documents/apcity/unpan020065.pdf > at 1 [last accessed 27 October 2012].

38 Supra, note 32 at 62.

39 Ibid. at 63.

40 (1999) 52 DLR (AD) 82. 
tain control over the lower judiciary, the magistracy in particular. Harry Blair notes that the Supreme Court, presumably anxious to avoid direct confrontation with the executive, continued granting extensions for the government to comply with these requirements ${ }^{41}$ It was only during the period of emergency declared by the caretaker government in 2007 that the implementation of this judgment began. Therefore, while political discourse professes commitment to judicial independence, practical measures have been too few.

The key issue of the non-separation of the judiciary from the executive is the politicization of the justice sector. Through the use of muscle politics and mastaans the party in power uses the magistracy and the criminal justice system to harass political opponents while absolving themselves of wrongdoing. As the Judicial Independence Overview conducted by the Asian Development Bank notes, "[t]oo often changes of government result in the dismissal of criminal and corruption cases against members of the newly instated ruling party and the institutionalization of dozens of criminal and corruption cases against ministers and important bureaucrats from the last government" 42 It is also alleged that High Court judges are increasingly recruited on the basis of systematic political calculation in order to ensure that in the near future Chief Justices will remain loyal to the ruling/appointing party. This system resulted from the 13th Amendment to the Constitution, which stipulates that the immediate past Chief Justice will head the neutral caretaker government. The decline of the independence of the judiciary, in violation of the Constitution, reinforces weak adherence to the rule of law through a failure to hold other organs of the government into account.

\section{Judicial activism and the rights movement}

Having set out the state of independence of the judiciary in Bangladesh we can now analyse the role that the judiciary has played in upholding fundamental rights and in developing PIL. Has the judiciary been "statist" and "developmentalist" as defined by Rajagopal: ${ }^{43}$ Or has it had the courage to take

41 H. Blair, 'Party Overinstitutionalization, contestation, and democratic degradation in Bangladesh' in Handbook of South Asian Politics (Routledge 2010) at ch. 6.

42 Asian Development Bank, 'Judicial Independence Overview and Country-Level Summaries' $<$ http://www2.adb.org/documents/reports/Law_Policy_Pov_Red/Part2.pdf $>$ at 44 [last accessed 27 October 2012].

43 B. Rajagopal, 'Pro-Human Rights but Anti-Poor? A Critical Evaluation of the Indian Supreme Court from a Social Movement Perspective', (2007) 18(3) Human Rights Review 157 at 158 . 
on the executive? In what circumstances has the judiciary been willing to stand up as a protector of rights and the Constitution?

Judicial activism and PIL are fairly recent concepts in the context of Bangladesh. PIL refers to "activist jurisprudence that enables someone without actually being aggrieved to activate the judicial method to pursue a public cause or the rule of law, and allows the court to provide unorthodox remedies.' ${ }^{44}$ PIL first took off in India in the 1970s and was seen as largely successful in terms of advancing progressive rights ${ }^{45}$ However, since democracy was only re-established in Bangladesh in 1991, PIL is a more recent phenomenon. Along with the restrictions imposed on the judiciary by martial law ${ }^{46}$ it is said that "the primary reason behind Bangladesh's belated embrace of PIL appears to have been judicial unwillingness to break away from colonial legal thinking and abandon constitutional textualism or legal formalism" ${ }^{47}$ It is only after 1991, and the return to democracy, that judges became willing to extend the application of the law as a result of overwhelming pressure from legal quarters and civil society.

In 1996, after a drawn-out jurisprudential battle, the High Court, in its landmark decision in Dr Mohiuddin Farooque $v$ Bangladesh ${ }^{48}$ liberalized the requirements of locus standi by granting standing to an environmental organization to challenge a flood control project. This was allowed on grounds of a rights violation and breach of the law. The Court stated that a liberal interpretation of the Article 102 phrase "a person aggrieved" should be taken based on the indigenous nature of the Constitution, which was not the outcome of a negotiation with a colonial power but the result of a war of independence fought by its people for a common cause. Based on the origins of the Constitution, the ambit of Article 102 could not be limited to a narrow understanding of an "aggrieved person" but must be read in a way to expand the concept of locus standi and the constitutional mandate for social justice and judicial consciousness.

PIL in Bangladesh started developing after the liberalization of locus standi in Dr Mohiuddin Farooque and gained momentum following the year 2000,

\footnotetext{
${ }^{44}$ Hoque, supra, note 8 at 399.

45 See U. Baxi, 'Taking Suffering Seriously: Social Action Litigation in the Supreme Court of India', in N. Tiruchelvam and R. Coomaraswamy (eds), The Role of the Judiciary in Plural Societies (Francis, 1987), 32-59.

46 See M.E. Bari, 'Martial Law in Bangladesh, 1975-1979: A Legal Analysis', Ph.D. thesis submitted to School of Oriental and African Studies, University of London, 1985.

47 Hoque, supra, note 8 at 400 .

48 IX (1996) Bangladesh Supreme Court Report 27.
} 
mainly because of judgments in environmental rights cases. Growing judicial environmental activism encouraged legal activists and NGOs to challenge a broad range of government actions and failures under the auspices of environmental rights. In order to receive positive judicial orders, many non-environmental rights claims were framed as environmental rights cases and brought as PIL. Challenges to corruption within the government was brought as environmental PIL by NGOs in the cases of Khushi Kabir $v$ Bangladesh $4^{49}$ BELA v Bangladesh (2002) ${ }^{50}$ and BELA v Bangladesh (2003) ${ }_{4}^{51}$ In these cases, the government allocation of land to a Member of Parliament for the purpose of shrimp cultivation was challenged on grounds of damage to the surrounding environment, and the leasing of river land was challenged to protect labour rights of unregulated workers in the ship-breaking industry. These cases set the tone for the use of PIL as a political tool.

In more recent cases, the judiciary has declared punishment on the basis of fatwa as extra-judicial $\left[{ }^{52}\right.$ made it illegal to force students or workers in public schools or offices to wear religious clothing ${ }^{53}$ and banned Islamic political parties. ${ }^{54}$ These orders show that the courts have been willing to embrace individual rights and interpret the fundamental rights broadly. It is interesting to observe that these judgments were issued during the tenure of the $\mathrm{AL}$, which is known for its secular stance ${ }^{55}$ and pro-Indian policies, following considerable press coverage and support from civil society.

In India, Rajagopal writes that "in cases relating to housing rights or the right to health, the Court has rarely shown the kind of aggressive public policy interventionism that it exhibits in other areas such as environment" 56 In Bangladesh, courts have addressed important policy issues concerning economic and social rights under the veil of protecting the right to life, among other constitutional rights. Hoque notes that judgments have been given which "seek to enlighten the executive (without specifically imposing positive

\footnotetext{
49 Writ Petition No. 3091/2001.

50 Writ Petition No. 4685/2002.

51 Writ Petition No. 2911/2003.

52 Writ Petition No. 5863 of 2009 and Writ Petition Nos. 754 and 4275 of 2010.

53 E. Bock, 'Bangladesh court rules against mandatory religious clothing', The Jurist, 22 August 2010, <http://jurist.org/paperchase/2010/08/bangladesh-court-rules-against-mandatoryreligious-clothing.php $>$ [last accessed 27 October 2012].

54 S. Alam, 'Bangladesh court bans religion in politics', 29 July $2010<$ http://www.google.com/ hostednews/afp/article/ALeqM5h_5T_bgbToWaGqK2gxXACMFuySog> [last accessed 27 October 2012].

55 The Constitution of the Bangladesh Awami League, Fundamental Principles.

56 Supra, note 43 at 161.
} 
obligations on it) about its duty to increase social justice and provide the people with the minimum necessities of life" 57

To understand these types of cases, it is important to look at the context of Bangladesh's political culture. The two selected cases illustrate that when the Supreme Court gives activist decisions, it does so with the backing of another institution (the opposition or the government coupled, with support from the media and popular opinion).

\section{Judicial decisions: background conditions}

In Ain O Shalish Kendra (ASK) v Bangladesh (Slum Dwellers) ${ }^{58}$ the Supreme Court held that the eviction of slums without the rehabilitation of slum dwellers amounted to a violation of the right to life. This case is important for three reasons. First, this decision had a significant impact on policy-making, the forte of the executive, and was of immense importance to what Justice Bhagwati described as the "teeming millions" 5 Second, the political nature of the circumstances surrounding this petition illustrates how the judiciary has been willing to give positive decisions and take a broad view of Article 32 when supported by other sectors of society, in this case the opposition. Third, the case provides an understanding of judicial attitudes to PIL and pro-people decisions soon after Bangladesh's return to democracy and liberalization of the locus standi rules. Some of the most activist decisions of the Supreme Court were given around the same time.

The second case reflects the manner in which judicial attitudes have shifted depending on who was in government. The Dhaka (Rangs Bhaban) trilogy dealt with the same high-rise building. In the first decision the Court stayed the demolition of the building, in the second it ordered the demolition, and in the third it directed the government to enforce the safety of construction workers after PIL following the partial collapse of the building during demolition that killed 13 people. This case is especially important because of the timing of each

57 Hoque, supra, note 8 at 405 .

5819 BLD (1999) 488.

59 The city of Dhaka is home to over 3 million slum dwellers. Each day brings 2000 newcomers to these slums. The impact of the judgment has been felt each year, most recently in Korail in March 2012 when approximately 2000 structures were bulldozed in accordance with the Supreme Court directions but nonetheless in an inhumane manner, according to NGOs. See V. Subramanian and M.A. May, 'Korail slum eviction in Dhaka: notes from the field', 9 April $2012<$ http://www.globalhealthhub.org/2012/04/09/korail-slum-eviction-in-dhakanotes-from-the-field/> [last accessed 27 October 2012]. 
decision: the stay, the demolition order, and the workers safety order. The moments in which each judgment was given illustrates that perhaps there is more influencing judicial behaviour than simply the legal merits of a case.

\subsection{Case Study 1: Ain O Salish Kendra (ASK) v Bangladesh (Slum Dwellers)}

Article 15 of the Constitution provides that the government has a responsibility to supply basic necessities, including shelter. Article 31 and 32 protect the right to life. The High Court has read Article 15 along with Articles 31 and 32 to provide the right to livelihood and the right to shelter. A number of writ petitions in the form of PIL have been brought to the court in relation to the eviction of slum dwellers, arguing that the rights under Articles 15, 31, and 32 were infringed ${ }^{60}$ Generally, judicial decisions have held that, while the government does not have the responsibility to immediately provide shelter to all persons, it does have a responsibility to ensure that citizens are not arbitrarily or forcibly evicted. High Court decisions have determined that, before evicting slum residents from their dwellings, the government must provide written notice, and, through an interpretation of the state's obligations to ensure protection from forced eviction, have required the authorities not to carry out any eviction without prior rehabilitation or resettlement ${ }^{61}$ Thus, we see very proactive judgments on the part of the courts in relation to economic and social rights and a willingness on the part of NGOs to utilise PIL for the development of such rights. In this case, it is important to highlight the background conditions behind the first slum eviction orders given by the Supreme Court and show how NGOs became involved after the opposition picked up on the issue in order to damage the government's reputation. The courts also directly confronted the government in a case that was hugely publicized and received support from the opposition and civil society, but they ultimately backed down when harassed by the executive.

In August 1999, the government started a major slum clearance program on the basis of improving law and order and to flush out terrorists and drug dealers. The opposition, however, charged that the clearance was politically motivated and aimed at cleaning out voters who could pose a threat to the reelection of a local AL member of parliament and enhance the standing of

${ }^{60}$ BLAST, 'Right to Shelter' <http://www.blast.org.bd/issues/shelter > [last accessed 27 October 2012].

6119 BLD (1999) 488, judgment delivered on 29 July 2001. 
the party among non-slum voters in the impending Dhaka mayoral elections. The eviction drive attracted major attention and criticism from the media and opposition, resulting in three NGOs and two slum organizations obtaining a stay from the High Court ${ }^{62}$

At the time the writs were filed, the AL government was already at odds with the judiciary over a number of adverse rulings involving the illegal detention of three opposition leaders under the Special Powers Act and the court's role in reviewing an anti-defection case involving two BNP members of parliament who switched allegiance to the $\mathrm{AL}{ }^{63}$ The Supreme Court was scheduled to hear the writs filed against the slum clearance operation on 19 August. However, on the night of 18 August, thousands of slum dwellers, tempted by promises of rehabilitation by AL leaders, entered the grounds of the Supreme Court and began to build makeshift houses on the lawn, turning them into a slum colony. An embarrassed High Court turned the case over to the Chief Justice, who assigned it to another bench of the court and set a new date of 23 August for the hearing. Using the same tactic, the government induced a group of slum dwellers to march in front of the house of Kamal Hossain, the lawyer involved in the case, and set up a slum colony on the sidewalk in front of his home 64

Despite requests by the Court to the police and the Home Ministry to remove the slum dwellers from the grounds, neither took action and cited the High Court's stay order on eviction. In fact, the government did not deny their role in encouraging the slum dwellers to occupy the Court's compound and the street in front of Kamal Hossain's house. The Minister lashed out at the courts, the NGOs and the opposition for opposing an eviction that enjoyed widespread popular support. According to the Minister, government land was being used for illegal slums that would become dens of terrorists, drug dealers and antisocial elements. He claimed that the government had a plan to rehabilitate the slum dwellers and condemned NGOs for spreading falsehoods.

The government's behavior toward the slum dwellers came under sharp criticism from the legal community, NGOs, and Western donors as a violation of human rights ${ }^{65}$ Kamal Hossain called the occupation of the Court grounds "unprecedented" and commented that " $[\mathrm{t}] \mathrm{he}$ Supreme Court is a constitutional body and those responsible for protecting the court must be held accountable".

${ }_{62}$ Dhaka Courier, 20 August 1999.

${ }^{63}$ In all of these cases we see how the courts in Bangladesh have become another forum for political competition and animosity.

${ }^{64}$ Supra, note 62.

65 S. A. Kochanek, 'Governance, Patronage Politics and Democratic Transition in Bangladesh', (2000) 40(3) Asian Survey 530 at 544. 
The incident, he insisted, amounted to contempt of the Court and an embarrassment to the entire nation 6

The government defended its actions and the Prime Minister spoke out against the NGOs responsible for filing the writ petitions. She accused these NGOs, most of which worked amongst the slum dwellers, of embezzling billions of Taka that had been ear-marked for slum dweller rehabilitation. The NGOs in turn called the campaign against slum dwellers state-sponsored terrorism and charged that the real purpose of the operation was to take over the land so that it could be sold 67

The High Court finally dispensed with the writ petition by ordering the eviction of the slum dwellers from the Supreme Court premises and allowing the government to proceed with the evictions with the advice that it be done in stages to facilitate rehabilitation.

Thus, in this case, we see that NGOs used judicial avenues for upholding human rights only after the opposition and the press got involved, perhaps indicating the elite-driven nature of PIL that combines political motives with a desire for media attention. Similarly, the courts were willing to take a strong stance when they received encouragement from the opposition, the media and the international community. However, when its own grounds came under attack the judges backed down and allowed the executive to proceed.

\subsection{Case Study 2: BLAST v Bangladesh}

In BLAST v Bangladesh ${ }^{68}$ two NGOs, the Bangladesh Legal Aid and Service Trust ("BLAST") and the Occupational Safety Health and Environment Trust ("OSHE") initiated PIL challenging the government on the failure of the Ministry of Housing and Public Works to secure compliance with safety and security regulations as provided in the Bangladesh National Building Construction Code 2006. It was argued that injuries and deaths resulting from the demolition of a high-rise building violated Article 32 of the Constitution and the right to life. The High Court disposed of the case in November 2011 with an order directing the government to secure immediate compliance with the safety regulations and to establish a code-enforcement agency. Further, the government was directed to submit progress reports to the Court at the end of three months. While this case was a victory for the NGOs and construction

\footnotetext{
${ }^{66}$ Dhaka Courier, 27 August 1999.

67 Dhaka Courier, 13 August 1999; Dhaka Courier, 20 August 1999; Dhaka Courier, 27 August 1999.

68 Writ Petition No. 718 of 2008.
} 
workers, and a pro-rights decision by the Court, it is interesting to see the events that led to the PIL and the judgment.

In 1999 a suit was filed against Dhaka's City Development Authority ("RAJUK") asking for the stay of an order of demolition. ${ }^{69}$ "Rangs Bhaban", a 22 -storied building was constructed after receiving appropriate approvals and permissions from RAJUK. However, because there was an aerodrome nearby, when the building was completed up to the 16th floor, the Bangladesh Air Force Head Quarters objected and asked RAJUK to demolish the high-rise construction beyond the permissible height set by the Civil Aviation Rules. RAJUK issued an order to the plaintiff to demolish the construction beyond the 6th floor, which was the permissible limit. The owners filed a suit against RAJUK. In May 2000, the High Court gave a verdict rejecting RAJUK's order to demolish the building on the grounds that RAJUK had neglected the question of legality when it decided to revoke its permission to construct the building. The Court emphasized that the construction had cost millions in accordance with a plan approved by RAJUK and therefore it was a property lawfully vested to the plaintiffs.

This decision was criticized on the grounds that the owners of Rangs Bhaban, large industrialists in Bangladesh, had acquired the rights to the land and the permission to construct the building illegally through contacts with influential ministers. It was also criticized because if the building was demolished and the land acquired by the government, a road linking two highways could have been built 70 RAJUK filed an appeal but did not pursue it.

In January 2007, after months of street violence, economic disruptions and governmental paralysis, during which time the AL accused the BNP of preparing to rig the impending elections, the sitting caretaker government was replaced by an army-backed government. Elections were postponed indefinitely and a state of emergency was declared. One of the main agendas of the new government was to tackle corruption. The government arrested hundreds of political and business "bigwigs" 71 Rangs Bhaban at this time was seen as a "symbol of abuse of power" as stated by the Law and Public Works Advisor ${ }^{72}$ The government reactivated the appeal for the demolition

692000 DLR 52.

70 Y. Suzuki and D. Miah, 'Alternative Visions of Incomplete Property Rights', Ritsumeikan Asia Pacific University, Working Paper No. 07-5, December 2007, at 11.

71 Iftekharuzzaman, 'Making the Anti-Corruption Commission Effective: Why and How?' (Draft), Transparency International Bangladesh at 4.

72 The Daily Star, 3 August 2007 (Dhaka). 
of the building. During the tenure of the army-backed caretaker government, the Appellate Division overturned the High Court ruling and ordered the demolition of Rangs Bhaban. This was seen as a major success of the caretaker government and a win against corruption. As observed by one blog:

Rangs Building is the monument of illegality. This is an example of how the influential in Bangladesh ignore rules of the land and ignore the orders of the governmental authorities. It shows how they influence the laws and ignore the courts. No political government so far could do anything in this regard and the owners were so confident that they invested about 700 crore taka in constructing this. This confidence came from the political linkage they have developed over the years with the political parties and our legal system. ${ }^{73}$

Thus, though not filed as a PIL, we see how the support of the army-backed caretaker government and popular opinion perhaps encouraged the courts to issue a decision against a large and influential business interest.

The Rangs Bhaban suit illustrated how courts and the prosecution often need government backing and popular support in order to pursue pro-people decisions. But it is also necessary to discuss how the decision given in the Rangs Bhaban case led to the NGOs filing a PIL and the judgment given in BLAST $v$ Bangladesh.

Following the order of the Appellate Division in A Rouf Chowdhury $v$ Bangladesh, the government took immediate steps to start the demolition. However, on 8 December 2007, nearing the end of the tenure of the army-backed caretaker government, part of the 17th floor caved in demolishing the floors beneath it. 13 people were killed while 100 others were injured 74 With the popularity of the caretaker government waning, there was already a loud voice criticizing the demolition of one of Dhaka's tallest buildings because of the cost of building it and the number of businesses that had operated in the commercial space ${ }^{75}$ Criticism also focused on the way that the caretaker government carried on with the demolition ${ }^{76}$ Ironically, the demolition and deaths began to be seen as a symbol of the failure of the caretaker government.

\footnotetext{
73 'Rangs building "symbol of abuse of power" demolished', 3 August $2007<$ http://bdoza. wordpress.com/tag/rangs-building/> [last accessed 27 October 2012].

74 The Daily Star, 8 May 2008 (Dhaka).

75 The Daily Star, 3 August 2007 (Dhaka).

76 The Financial Express, 5 August 2007 (Dhaka).
} 
Following these events BLAST started an investigation on the cause of the deaths from the collapse and found that the company assigned to demolish the building did not comply with the necessary safety measures. When AL came to power, the BLAST $v$ Bangladesh case was initiated.

This case and the events that led up to it show that, although the judiciary in Bangladesh has been open to giving pro-people judgments, this is often done on the basis of support from other institutions, whether it is the government, the opposition, the media, or a popular social movement.

\section{Conclusion}

Charles Epp criticises the Indian rights revolution on the grounds of weak structural support and therefore failure to both encourage and take advantage of judicial activism. He states that the "Indian interest group system is fragmented, the legal profession consists primarily of lawyers working individually, not collectively, and the availability of resources for noneconomic appellate litigation is limited"77 There has therefore been a weak growth of the human rights agenda since the post-emergency time. Likewise, in Bangladesh, NGOs have utilised legal channels for the protection of human rights when they have been motivated by self-interest, such as attracting media attention, or for political purposes.

As can be seen from Ain O Shalish Kendra (ASK) v Bangladesh (Slum Dwellers), PIL has been employed when there has been a partisan agenda and the courts have been used as a forum to attack the incumbent by the opposition, when other avenues, especially parliament, has been monopolized by the party in power through modes of dynastic and highly centralized governance. In terms of the courts, the judiciary has been proactive in giving judgments in favour of the rights agenda only when it falls within Rajagopal's "statist" and "developmentalist" 78 boundaries, such as in environmental rights litigation. Judgments that have an impact on policy or threatened the monopolization of power by the executive and the patronage structure of politics are only forthcoming when the decision would be largely supported by the public and social movement organizations. In BLAST v Bangladesh, the Appellate Division overturned the High Court's decision during the tenure of the army-backed caretaker government seven years after the original stay on demolition, perhaps

\footnotetext{
77 C.R. Epp, The Rights Revolution, Lawyers, Activists and Supreme Courts in Comparative Perspective (University of Chicago Press, 1998) at 95.

78 Supra, note 43 at 158.
} 
because the government and popular support lay with demolition. The judiciary failed to take the political parties head-on as can be seen in their acceptance of the postponement of the implementation of Secretary, Ministry of Finance v Md. Masdar Hossain, although it relates to their own independence, and in the benign instructions finally handed out in Ain O Shalish Kendra (ASK) $v$ Bangladesh (Slum Dwellers). Further, partisan and patronage politics have infiltrated the courts, not only at the lower levels but also at the apex levels, through a system of non-separation of the executive and the judiciary and the level of control that the executive holds over judicial appointments and budgets.

It would seem that PIL in Bangladesh is motivated by elitist agenda. Much PIL involves political motivations and is principally driven by elites, consisting of individuals, associations of individuals, political pressure groups such as lawyers' bodies, civil society representatives and NGOs. The solution to the problem of a volatile civil liberties movement influenced by the political mood of the time does not seem to be an easy one.

Ridwanul Hoque writes that "PIL has a political and social function in that it seeks constantly to reshape and rebalance power relations" 79 Although there are limits to the judicial and NGO development of human rights through PIL, because of its elitist and political nature, it is important to point out that the elitist use of PIL has been a global phenomenon. Hoque argues that elites will, for the time being, continue to occupy the central position in the movement towards social change through the judicial enforcement of law given the nature in which Bangladeshi society operates. Therefore, as long as PIL upholds genuine complaints by the public and supports the realization of a constitutionally-promised just society, it will be an avenue towards justice.

Despite risks of opportunistic and politically motivated uses of PIL, an activist judiciary can successfully use PIL to hold the executive accountable for its actions and failures encroaching on fundamental rights as well as other constitutional issues, even when it is does so only when backed by other sectors. The judgments discussed in this paper, though fueled by support from institutions other than the judiciary or NGOs, show that the use of PIL has established social and economic rights for the poor. In Ain O Shalish Kendra (ASK) v Bangladesh (Slum Dwellers), the eviction of slum dwellers without prior rehabilitation was declared illegal, while in BLAST $v$ Bangladesh, the safety of construction workers became an important state concern. The existing scenario in Bangladesh of "social deprivation and injustice, lack of rule of law, bad governance, and the flouting of the constitutional norms, rights and

\footnotetext{
${ }_{79}$ Hoque, supra, note 8 at 409.
} 
mandates in running the business of the state is, by and large, a product of the lack of public accountability" 80 In this context, PIL and judicial activism can be used to hold the executive accountable through judgments that enforce constitutional standards and fundamental rights, even when influenced by third parties. Regardless of the background conditions that gave rise to the decisions in these cases, the fact remains that the government must comply with the orders of the Supreme Court, and whatever may have been influencing factors for the decisions, they are ultimately supportive of social justice.

${ }^{80}$ Ibid. 